\title{
Bioactive Prodigiosin Isolated from Serratia marcescens using Solid State Fermenter and its Bactericidal Activity Compared with Conventional Antibiotics
}

\author{
Arivizhivendhan $\mathrm{KV}^{1}$, Mahesh $\mathbf{M}^{2}$, Regina Mary $\mathbf{R}^{1 *}$ and Sekaran $\mathbf{G}^{2 *}$ \\ ${ }^{1} P G$ \& Research Department of Zoology, Auxilium College, Vellore, India \\ ${ }^{2}$ Environmental Technology Division, Central Leather Research Institute (CSIR), Chennai, India
}

\begin{abstract}
The prodigiosin was isolated from Serratia marcescens and the production process was optimized by response surface methodology-central composite design (CCD). The bactericidal efficiency of prodigiosin was analyzed against antibiotic resistant pathogens. The maximum yield of prodigiosin $(70.4023 \mathrm{~g})$ was achieved per $\mathrm{kg}$ of tannery fleshing at optimized condition time, $81.2 \mathrm{~h}$; temperature, $29^{\circ} \mathrm{C} ; \mathrm{pH}, 6.8$; moisture, $50 \%$. The prodigiosin exhibited complete inhibition of the growth of Pseudomonas aeruginosa compared with other conventional antibiotics which is confirmed by disc diffusion method, LIVE/DEAD assay and fluorescence emission image. Prodigiosin, the bioactive compound was produced from tannery solid waste in solid state fermentation. The antimicrobial effect prodigiosin antibiotic resistant pathogens may make a possible platform in future for bacterial disinfection in clinical/ pharmaceutical wastewater.
\end{abstract}

Keywords: Serratia marcescens; Prodigiosin; Tannery fleshing; Solid state fermenter; Antibiotic resistant bacteria

\section{Introduction}

The tannery fleshing is proteinaceous solid waste generated from leather industries during leather manufacturing process. Tannery fleshing (TF) constitutes about 50 to $60 \%$ of solid wastes generated from the leather industry [1]. They are dumped onto open land, digested in anaerobic digester or incinerated in thermal incinerators [2-4]. The inherent disadvantages associated with these disposal techniques are huge energy consumption, large retention period and objectionable odor emission [5]. The TF contains adequate carbon and nitrogen contents, besides the essential amino acids and favorable moisture content for the growth of microorganisms [6,7]. Despite the $\mathrm{TF}$ is the rich source of protein $(50-60 \%)$ with moderate fat content (6$7 \%$ ), it is underutilized due to the lack of viable technology. Prodigiosin is bioactive alkaloid compound, the secondary metabolite usually accumulates during the later stage of microbial growth in the process of submerged fermentation. Prodigiosin has pharmacological activity such as anticancer, antimicrobial, immunosuppressive, antimalarial and antiprotozoal. Lapenda JC et al has reported prodigiosin is the effective antimicrobial agent against gram negative and gram positive bacteria [8]. Despite wide pharmacological applications, the production of prodigioisin has not yet reached the economically viable process. Prodigiosin production depends on carbon and nitrogen sources of the substrate. The high carbon and nitrogen sources containing TF may support the production of prodigiosin. Sumathi et al. (2014) reported that TF was considered as the potential substrate for the production of prodigiosin in submerged fermentation [9]. The prodigiosin production was carried out in submerged fermentation and limited TF concentration (4\%) was utilized with low yield of the prodigiosin. Moreover, separation of prodiogiosin through extraction from the submerged fermentation involves huge amount of solvents. Solid state fermentation (SSF) has been gaining renewed interest and focused attention from researchers owing to its importance in recent developments in biomass energy conservation. SSF has many advantages over submerged fermentation reactor including higher production yield, more effectiveness, more eco-friendly $[10,11]$ and easy recovery of byproduct. Hence, the focal theme of the present investigation was to produce prodigiosin from proteinaceous $\mathrm{TF}$ through solid state fermentation using Serratia marcescens and to compare its bactericidal activity against Pseudomonas aeruginosa with conventional antibiotic compounds.

\section{Materials and Methods}

\section{Isolation and characterization of microorganisms}

The limed tannery fleshing was collected from a commercial tannery in Chennai, Tamilnadu, India. It was mixed with soil in the ratio of 1:1 and kept for 30 days. After $30^{\text {th }}$ day $1 \mathrm{~g}$ of composted material was collected and diluted with $10 \mathrm{ml}$ of saline solution $(0.85 \% \mathrm{NaCl})$, from this $1 \mathrm{ml}$ was spread onto nutrient agar and incubated at $30^{\circ} \mathrm{C}$ for $24 \mathrm{~h}$. The red colour bacterial strain was isolated and cultivated in nutrient broth (peptic digest of animal tissue $5 \mathrm{~g} / \mathrm{l}$; sodium chloride $5 \mathrm{~g} / \mathrm{l}$; beef extract $1.5 \mathrm{~g} / \mathrm{l}$; yeast extract $1.5 \mathrm{~g} / \mathrm{l})$. This culture was used for the production of prodigiosin in Solid state fermenter (Figure 1). The basic biochemical tests were performed for the isolated red bacteria. DNA was extracted and sequencing was analyzed using the following method. $500 \mu \mathrm{l}$ of $24 \mathrm{~h}$ old culture was added to $150 \mu \mathrm{l}$ of TE buffer (10 mM TRIS-HCl, $\mathrm{pH} 8.0$, EDTA1 $\mathrm{mM}$ ) containing $8 \mu$ proteinase $\mathrm{K}(20 \mathrm{mg} / \mathrm{ml})$ and $0.5 \%$ SDS and incubated at $56^{\circ} \mathrm{C}$ for $1 \mathrm{~h}$. An equal volume of phenol: chloroform: isoamyl alcohol mixture was added and centrifuged at 15,600 $\mathrm{g}$ for 5 minutes. The aqueous phase was removed and DNA was precipitated with 0.1 volume of $3 \mathrm{M}$ sodium acetate $(\mathrm{pH}$ 5.2) and absolute ethanol ( 2 volumes). It was cooled at $-20^{\circ} \mathrm{C}$ for 30

*Corresponding authors: Sekaran G, Environmental Technology Division, Central Leather Research Institute (CSIR), Chennai, India, Tel: +91-44-24911386; Fax: +91-44-24452941; E-mail: ganesansekaran@gmail.com

Regina Mary R, PG \& Research Department of Zoology, Auxilium College, Vellore, India, Tel: 9952355724; E-mail: arivizhi@gmail.com

Received August 31, 2015; Accepted September 18, 2015; Published September 25, 2015

Citation: Arivizhivendhan KV, Mahesh M, Regina Mary R, Sekaran G (2015) Bioactive Prodigiosin Isolated from Serratia marcescens using Solid State Fermenter and its Bactericidal Activity Compared with Conventional Antibiotics. J Microb Biochem Technol 7: 305-312. doi:10.4172/1948-5948.1000230

Copyright: () 2015 Arivizhivendhan KV, et al. This is an open-access article distributed under the terms of the Creative Commons Attribution License, which permits unrestricted use, distribution, and reproduction in any medium, provided the original author and source are credited. 


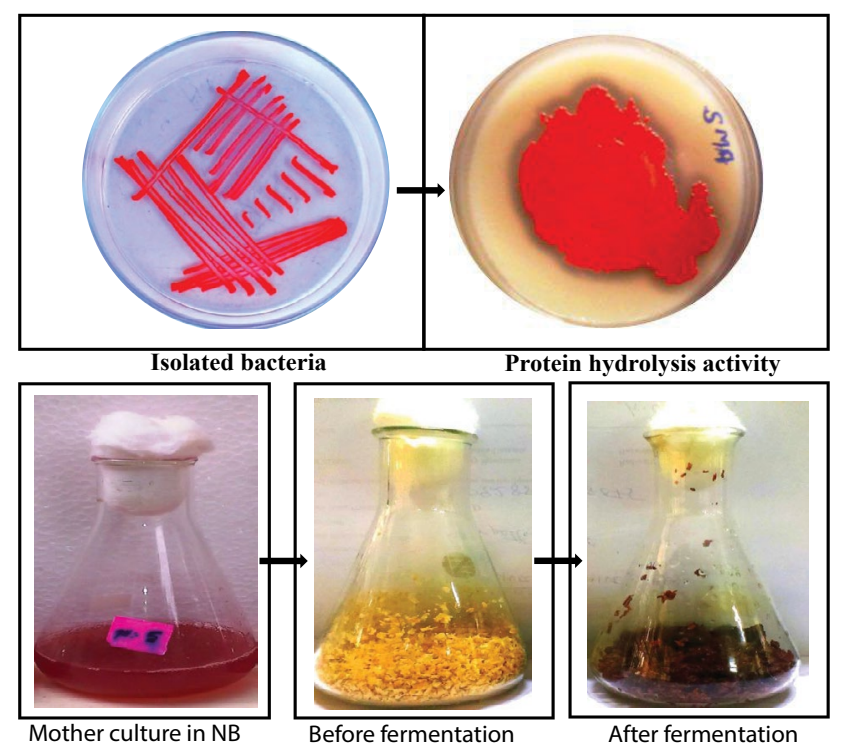

Figure 1: The isolate Serratia marcesance in different cultivation medium for prodigiosin production: a) isolation of Serratia marcesance, b) proteolytic activity of Serratia marcesance, c) mother culture, d) initial fermentation mixture, e) prodigiosin containing fermented mixture

minutes, the precipitated DNA was washed again with $70 \%$ ethanol, dried, and reconstituted in $20 \mu \mathrm{l} \mathrm{TE}$ buffer and stored at $-20^{\circ} \mathrm{C}$ until use. The small subunit rRNA gene was amplified using primers $27 \mathrm{~F}$ (AGAGTTTGATCMTGGCTCAG) and AGAGTTTGATCMTGGCTCAG (TACGGYTACCTTGTTACGACTT) primers for bacteria, and then performed 35 amplification cycles at $94^{\circ} \mathrm{C}$ for $45 \mathrm{sec}, 55^{\circ} \mathrm{C}$ for 60 sec, and $72^{\circ} \mathrm{C}$ for $60 \mathrm{sec}$. The PCR product was sequenced using the 518F (CCAGCAGCCGCGGTAATACG) and 800R (TACCAGGGTATCTAATCC) primers [12]. The 16S rRNA sequence was analyzed for the similarity and homology with the existing sequences available in National Center for Biotechnology Information (NCBI) data base using BLAST search.

\section{Preparation of substrate}

Wheat bran was purchased from a commercial outlet and screened to remove impurities, washed with water to remove grit materials and dried. It was milled with an electric wearing blender and sieved through $20-40 \mathrm{~mm}$ mesh sieve to get an uniform size fraction. Limed $\mathrm{TF}$, the major solid waste generated from the tanneries during leather manufacture. It was collected from a commercial tannery in Chennai, Tamilnadu, India. It was treated with ammonia solution $(25 \% \mathrm{v} / \mathrm{v})$ for 3 to $4 \mathrm{~h}$ to remove the adhered calcium salts from TF. The TF was further washed in running water and cut into small pieces ( $1 \mathrm{~mm}$ diameter) then stored at $4^{\circ} \mathrm{C}$ for further experiments.

\section{Fermenter design and experimental setup}

The fermenter consists of acrylic roller bottle of volume $1.61 \mathrm{~L}$ (length, $17 \mathrm{~cm}$ and width, $11 \mathrm{~cm}$ ) connected to a filtered air supply source at the rate of $20 \mathrm{~mL} / \mathrm{min}$ (Figure 2). The acrylic bottle was placed in a roller system, operated by a motor, to facilitate continuous rotation. The prodigiosin production media containing $1 \mathrm{Kg}$ of fermented mixture (wheat bran, $700 \mathrm{~g}$ and $\mathrm{TF}, 300 \mathrm{~g}$ ) was supplemented with minimal medium of volume $500 \mathrm{~mL}\left(\mathrm{Na}_{2} \mathrm{HPO}_{4} 7 \mathrm{H}_{2} \mathrm{O}, 33.90 \mathrm{~g}\right.$; $\mathrm{KH}_{2} \mathrm{PO} 4$, $15 \mathrm{~g} ; \mathrm{NaCl}, 2.5 \mathrm{~g} ; \mathrm{NH}_{4} \mathrm{Cl}, 5 \mathrm{~g} / \mathrm{L}$ ) and $10 \%$ of inoculum was added to the

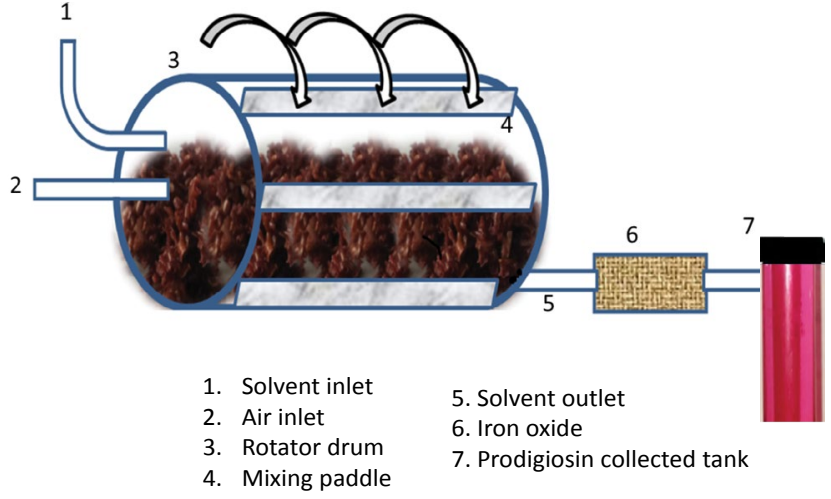

Figure 2: Schematic diagram of Laboratory scale fermenter.

fermenter. The optimization of the prodigiosin production was carried out with different environmental factors such as time, temperature, $\mathrm{pH}$, substrate concentration, moisture content and agitation. The optimization study was carried out by central composite design using design expert 8 software. The minimum and maximum values of the factors were entered into the software then the software automatically generated 50 experimental condition. The prodigiosin produced under the above 50 experimental condition were analyzed in laboratory scale fermenter and the values were enter into software. The significance of the experimental values were analyzed through ANOVA. Prodiogiosin was extracted from one gram of fermented SSF mixture by using various solvents (acetone, ethanol, methanol, isopropanol, benzene, hexane, diethyl ether, chloroform, dichloromethane, dimethyl sulfonate or petroleum ether) of volume $10 \mathrm{ml}$ separately. The prodigiosin concentration was determined in each eluted solvent. The solvent which extracted high prodigiosin was used in further experiments to elute prodigiosin from fermented SSF mixture. After fermentation of $\mathrm{TF}$, the solvent was added into the rotating fermenter and the solvent was collected from the fermenter outlet. The purified prodigiosin was characterized by UV-visible spectrum, high performance liquid chromatography and nuclear magnetic resonance spectrum. The presence of prodiogiosin in the SSF mixture was confirmed by diffuse reflectance spectrophotometer (Varian TCA Cary 300) at $\lambda_{200-800} \mathrm{~nm}$.

\section{Statistical analysis}

The central composite design was used to optimize the most significant factors for improving prodigiosin production. The five independent factors were studied at three different levels and a set of 50 experiments were carried out (Table 1). Design expert, version 8.0.7 (statease Inc., Minneapolis, USA) was used for the experimental designs and regression analysis of the experimental data. Statistical analysis of the model was performed to evaluate the analysis of variance (ANOVA). The quality of the polynomial model equation was judged statistically by the coefficient of determination $\mathrm{R}^{2}$ and its statistical significance was determined by an f-test.

\section{Antimicrobial activity of prodigiosin}

The antibacterial activity of prodigiosin was evaluated against Pseudomonas aeruginosa using the disc diffusion method. The pathogens, Pseudomonas aeruginosa was grown overnight on Muller Hinton agar plates. $24 \mathrm{~h}$ matured colonies were suspended into sterile saline $(0.9 \%)$ solution of volume $5 \mathrm{~mL}$ and the density of the suspension was adjusted to approximately $3 \times 10^{8}$ colony forming units $(\mathrm{CFU} / \mathrm{mL})$. 
Citation: Arivizhivendhan KV, Mahesh M, Regina Mary R, Sekaran G (2015) Bioactive Prodigiosin Isolated from Serratia marcescens using Solid State Fermenter and its Bactericidal Activity Compared with Conventional Antibiotics. J Microb Biochem Technol 7: 305-312. doi:10.4172/19485948.1000230

\begin{tabular}{|c|c|c|c|c|c|c|c|c|}
\hline Factor & Parameter & Units & Minimum & Maximum & Coded & Values & Mean & Std. Dev. \\
\hline A & Time & hour & 38.91806 & 153.08194 & $-1.000=72.00$ & $1.000=120.0$ & 96 & 22.33772 \\
\hline B & $\mathrm{pH}$ & & 2.24317 & 11.75683 & $-1.000=5.00$ & $1.000=9.00$ & 7 & 1.86148 \\
\hline C & Temperature & ${ }^{\circ} \mathrm{C}$ & 18.10793 & 41.89207 & $-1.000=25.00$ & $1.000=35.00$ & 30 & 4.65369 \\
\hline D & TF concentration & $\%$ & 6.21586 & 53.78414 & $-1.000=20.00$ & $1.000=40.00$ & 30 & 9.30739 \\
\hline $\mathbf{E}$ & Moisture & $\%$ & 26.21586 & 73.78414 & $-1.000=40.00$ & $1.000=60.00$ & 50 & 9.30739 \\
\hline
\end{tabular}

Table 1: Factors tested in the solid state fermentation

The swab was used to inoculate the dried surface of $\mathrm{MH}$ agar plate by streaking completely over the surface of the agar, rotating the plate approximately by $90^{\circ}$ to ensure an even distribution of the inoculum. The medium was allowed to dry for about 3 min before adding a sterile paper disc of diameter $5 \mathrm{~mm}$. The antimicrobial efficiency of prodigiosin was compared with conventional antibiotic compounds purchased from Himedia such as ampicillin (SD002), tetracycline (SD037), erythromycin (SD013), bacitracin (SD003) and chloramphenicol (SD006). The prodigiosin and conventional antibiotic compounds $(1 \mathrm{mg})$ were dissolved separately in methanol of volume $10 \mathrm{~mL}$ to get a homogenous solution. The discs were immersed in the prodigiosin solution and dried at $50^{\circ} \mathrm{C}$ for $2 \mathrm{~h}$. Each disc was tapped gently down the agar to provide uniform contact and the plate was incubated at $37^{\circ} \mathrm{C}$ for $24 \mathrm{~h}$. The zone of clearance of each antibiotics and prodigiosin were measured. The bacterial removal efficiency of prodigiosin was assessed by fluorescent dye uptake capacity of the bacterial cell. One milligram of ampicillin, tetracycline, erythromycin, bacitracin and chloramphenicol ampicillin, and prodigiosin were added separately in distilled water of volume $5 \mathrm{ml}$. The mature Pseudomonas aeruginosa culture solution of volume $10 \%$ was added into the antibiotic containing solution and incubated for $2 \mathrm{~h}$ at $37^{\circ} \mathrm{C}$. The solutions were transferred into the illuminator and the fluorescence emission was recorded. Then $1 \mathrm{ml}$ of solution was mixed with $0.05 \mathrm{ml}(1 \mathrm{mg} / \mathrm{mL})$ of propidium iodide and SYTO 9 then it was incubated at room temperature for $2 \mathrm{~min}$. The cells were separated by centrifugation at $5000 \mathrm{rpm}$ for $10 \mathrm{~min}$ and pellets were re-suspended in $1 \mathrm{ml}$ of phosphate buffer $(\mathrm{pH}, 7.0)$. Then, the suspension of volume $20 \mu \mathrm{l}$ was transferred onto microscopic slide and captured its fluorescence images using fluorescence microscope (Olympus BX-61) using red filter.

\section{Results and Discussion}

\section{Isolation of microorganism and optimization of prodigiosin production}

The $16 \mathrm{~S}$ ribosomal RNA gene sequence of isolated red bacterial sp. was analyzed using similarity search tool blast. This indicated high degree of similarity (99\%) with Serratia marcescens. The Phylogenetic tree constructed based on Neighbor joining method using ClustalW software (Figure 3). The present investigation, the process parameters of SSF were optimized for prodigiosin production using CCD. The CCD was employed to determine the optimal levels of the factors that significantly affected prodigiosin production. The high and low levels with the coded levels for the factors are as presented in Table 1. Based on the regression analysis of the data from the Table 2, the effects of factors on prodigiosin production were predicted by the second order polynomial function. The statistical significance of equation was checked by f-test and ANOVA for the second order polynomial model as shown in Table 2. The precision of a model could be checked by the regression coefficient $\left(\mathrm{R}^{2}\right), 0.8708$. Linear and quadratic terms were both significant at $1 \%$ level. Therefore, the quadratic model was selected in this present investigation. The P-values were used as the tool to check the significance of each coefficient, which was necessary to understand the pattern of the mutual interactions between the

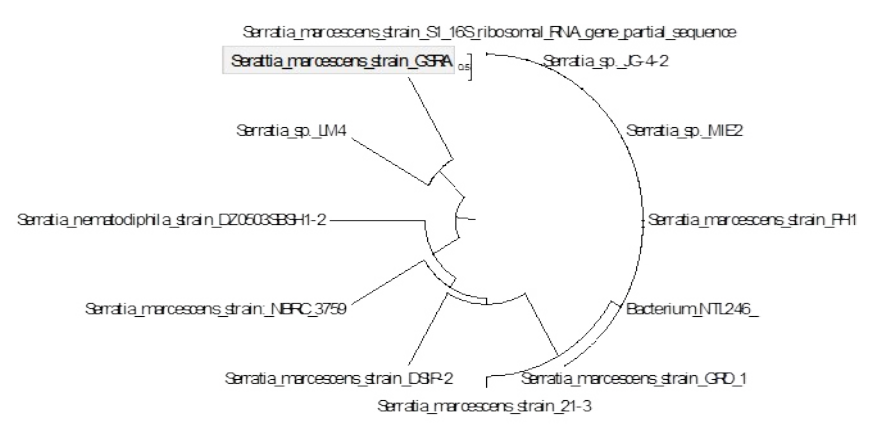

Figure 3: The Neighbour-joining phylogenetic tree based on 16S rRNA sequence of serratia marcesence

\begin{tabular}{|c|c|c|c|c|c|c|}
\hline Source & $\begin{array}{c}\text { Sum of } \\
\text { Squares }\end{array}$ & $\mathbf{d f}$ & $\begin{array}{c}\text { Mean } \\
\text { Square }\end{array}$ & $\begin{array}{c}\text { F } \\
\text { Value }\end{array}$ & $\begin{array}{c}\text { p-value } \\
\text { Prob > F }\end{array}$ & \\
\hline Model & 15964.52598 & 20 & 798.2263 & 9.77404 & $<0.0001$ & Significant \\
\hline A-Time & 468.0205 & 1 & 468.0205 & 5.73077 & 0.0234 & \\
\hline B-pH & 131.60701 & 1 & 131.60701 & 1.61149 & 0.2144 & \\
\hline C-Temperature & 478.18802 & 1 & 478.18802 & 5.85527 & 0.022 & \\
\hline $\begin{array}{c}\text { D-TF } \\
\text { concentration }\end{array}$ & 328.8718 & 1 & 328.8718 & 4.02694 & 0.0542 & \\
\hline E-Moisture & 212.4835 & 1 & 212.4835 & 2.6018 & 0.1176 & \\
\hline Residual & 2368.37136 & 29 & 81.66798 & & & \\
\hline Lack of Fit & 2368.37136 & 22 & 107.65324 & & & \\
\hline Pure Error & 0 & 7 & 0 & & & \\
\hline Cor Total & 18332.89734 & 49 & & & & \\
\hline
\end{tabular}

Table 2: ANOVA for the second order polynomial model.

best selected factors. Smaller P-values indicate the significance of the corresponding coefficients. The Model F-value of 9.77 implies the model was significant. There was only a $0.01 \%$ chance that a "Model F-Value" this large could occur due to noise.Values of "Prob $>$ F" less than 0.0500 indicate model terms are significant (Table 2). In this case $\mathrm{A}, \mathrm{C}, \mathrm{A}^{2}, \mathrm{~B}^{2}, \mathrm{C}^{2}, \mathrm{D}^{2}, \mathrm{E}^{2}$ are significant model terms. The Box-Cox plot is a tool to determine the most appropriate power transformation to apply to response data. Most data transformations could be described by the power function, $\sigma=f n\left(\mu^{\alpha}\right)$, where sigma $(\sigma)$ is the standard deviation, $\mu$ is the mean, and $\alpha$ is the power. Lambda $(\lambda)$ is $1-\sigma$ in all cases. Power law transformations can only be performed on responses that are greater than zero. A recommended transformation is listed, based on the best lambda value, which was found to be + at the minimum point of the curve generated by the natural log of the sum of squares of the residuals. The standard deviation associated with an observation is proportional to the mean raised to the power, then transforming the observation by $\lambda=0.5$ square root power gives a scale satisfying the equal variance requirement of the statistical model. The optimum conditions for the maximum prodigiosin yield $(70.4 \mathrm{~g})$ at time, $96 \mathrm{~h} ; \mathrm{pH}, 7$; temperature, $30^{\circ} \mathrm{C}$ and moisture content, $50 \%$ and mass of TF/ mass of SSF mixture 30\% (w/w) (Figure 4).

Prodigiosin production $=-651.6621 .638189 * \mathrm{~A}^{*} 42.2008 *$ 
Citation: Arivizhivendhan KV, Mahesh M, Regina Mary R, Sekaran G (2015) Bioactive Prodigiosin Isolated from Serratia marcescens using Solid State Fermenter and its Bactericidal Activity Compared with Conventional Antibiotics. J Microb Biochem Technol 7: 305-312. doi:10.4172/19485948.1000230
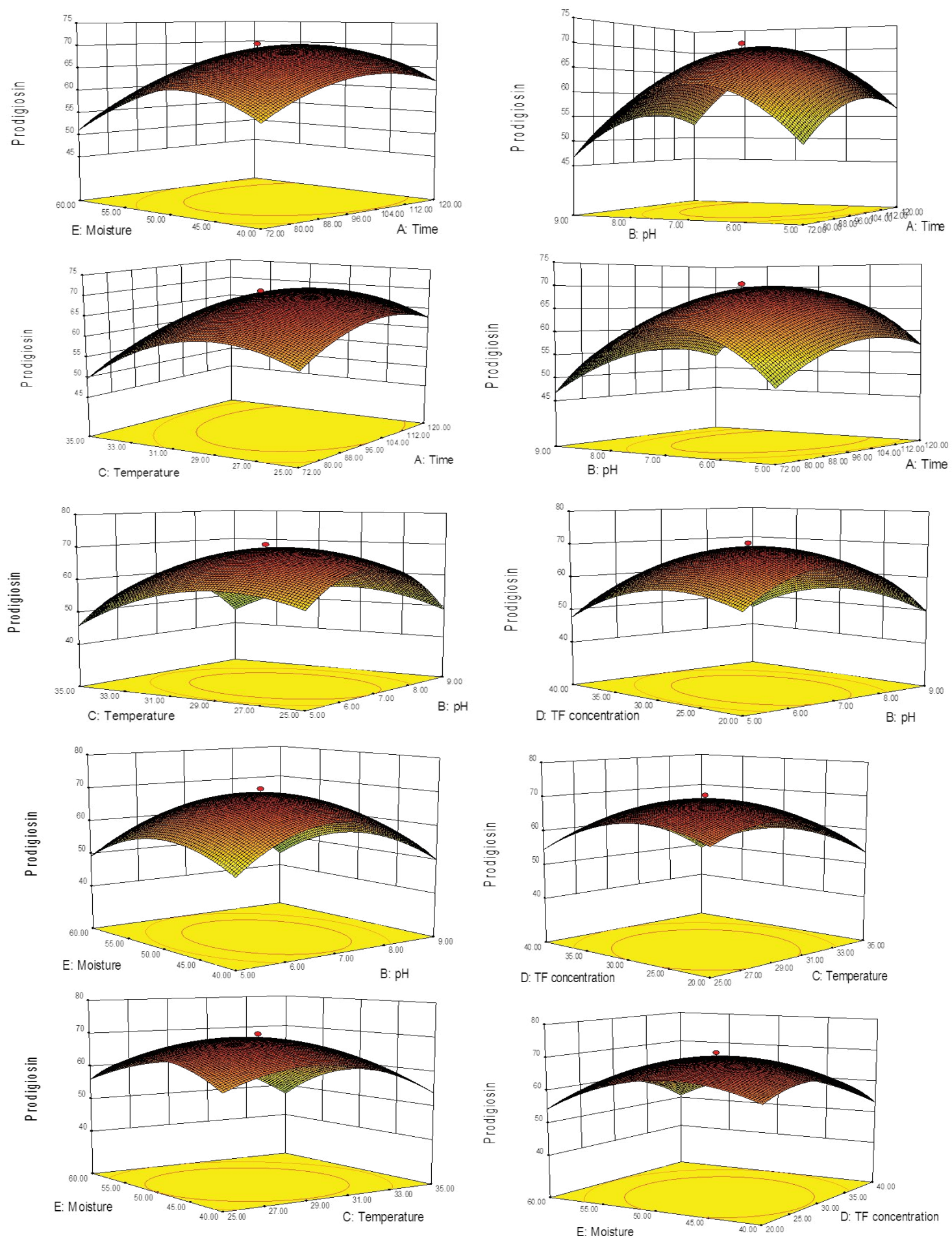

Figure 4: Optimization of prodigiosin production in solid state fermentation by RSM.

$\mathrm{C} 17.96603 * \mathrm{~B} 2.713859^{*} \mathrm{D} 8.028217 * \mathrm{E}-0.00421 * \mathrm{~A} * \mathrm{C} 0.00318 * \mathrm{~A}$ * $\mathrm{B} 0.000281^{*} \mathrm{~A} * \mathrm{D} 0.001216 * \mathrm{~A} * \mathrm{E} 0.118983 * \mathrm{C} * \mathrm{~B} 0.043777^{*} \mathrm{C} *$ $\mathrm{D}-0.04378^{\star} \mathrm{C}^{\star} \mathrm{E} 0.011225^{\star} \mathrm{B}{ }^{\star} \mathrm{D}-0.022{ }^{*} \mathrm{~B}{ }^{\star} \mathrm{E} 0.010102{ }^{\star} \mathrm{D}{ }^{\star} \mathrm{E}-0.00852$ ${ }^{*} \mathrm{~A}^{\wedge} 2-3.24016^{*} \mathrm{C}^{\wedge} 2-0.31676 * \mathrm{~B}^{\wedge} 2-0.06941{ }^{*} \mathrm{D}^{\wedge} 2-0.07703^{\star} \mathrm{E}^{\wedge} 2$

The optimized conditions were maintained in SSF bioreactor for the production of prodigiosin. The agitation speed has no much significant effect on production of prodigiosin (data not showed). The natural ventilation of the SSF reactor accessed enough oxygen for the metabolism of fermentative bacteria and in consequence a conducive condition for the production of prodigiosin was maintained. After 24 $\mathrm{h}$, the colour of the support matrix of SSF reactor was changed from light yellow to red, this was an indication that prodigiosin production 
Citation: Arivizhivendhan KV, Mahesh M, Regina Mary R, Sekaran G (2015) Bioactive Prodigiosin Isolated from Serratia marcescens using Solid State Fermenter and its Bactericidal Activity Compared with Conventional Antibiotics. J Microb Biochem Technol 7: 305-312. doi:10.4172/19485948.1000230

was initiated, on further increase in incubation up to $96 \mathrm{~h}$ the intensity of the red colour was increased (Figure 1). The prodigiosin was extracted from the fermented matrix of SSF reactor using different solvents such as acetone, ethanol, methanol, isopropanol, benzene, hexane, diethyl ether, chloroform, dichloromethane, dimethyl sulfonate or petroleum ether. Among these solvents tested, the acetone extracted the maximum concentration of prodigiosin from the fermented matrix (Figure 5). Fermentation matrix was rotated continuously for providing aeration into the contents of SSF reactor which inturn to support microbial community attached to the surface of the matrix [13]. Prodigiosin production levels are greatly influenced by nutritional and physicochemical factors, such as nitrogen and carbon sources, inorganic salts, temperature, $\mathrm{pH}$, agitation, and dissolved oxygen concentration [14-19]. Among them, the major factor influencing on prodigiosin production is medium composition. The production medium containing high protein content such as LB broth, nutrient broth, or peanut seed broth were found to support relatively high yields of prodigiosin and are usually better for pigment production in comparison to more defined media [16,19-21]. In general, carbohydrates were found to be poor nutrient sources for the production of prodigiosins, with glucose reported as a repressor of prodigiosin synthesis in Serratia marcescens [22,23]. Besides carbon source, the type of nitrogen source in the medium and the carbon-tonitrogen ratio also influenced the prodigiosin production. Overall, glycerol, glycine and fatty acids were found to be promising carbon sources or additives for increased production levels [24]. The influence of increased nitrogen sources on enhanced prodigiosin production. The maximum prodigiosin production was obtained with $\mathrm{TF}$ at $30 \%(\mathrm{w} / \mathrm{w})$, this is comparatively higher than previously reported by researchers as shown in Table 3 [9,14-19,24-28]. The prodigiosin production reported with many bacterial strains isolated from different sources and with different carbon and nitrogen sources were compared with the present investigation (Table 3). An effective prodigiosin production could be achieved by increasing TF concentration from 10

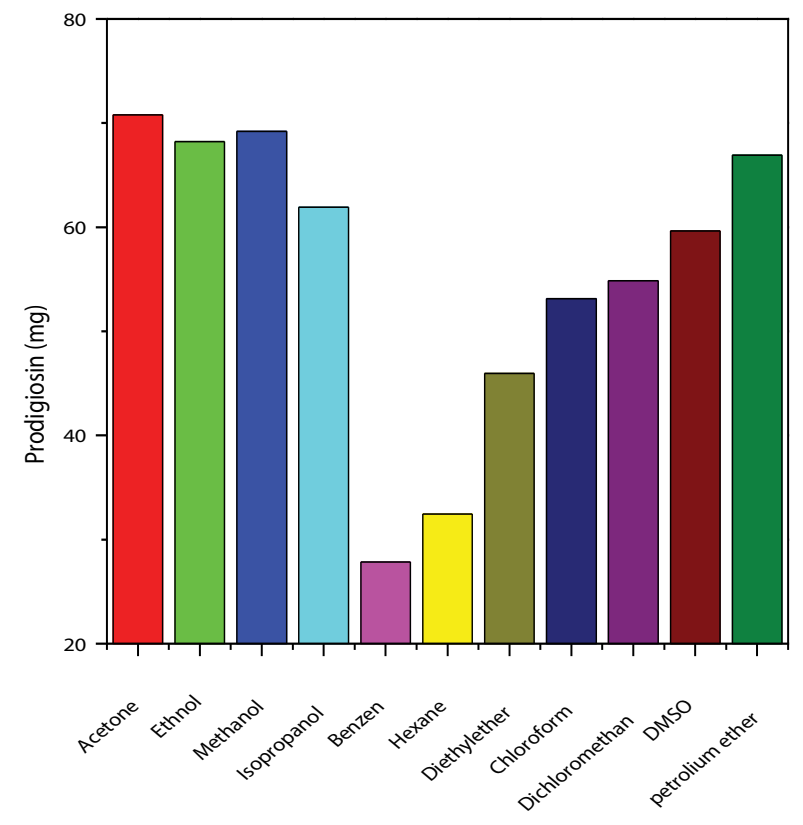

Figure 5: Organic solvents extractability of Prodigiosin in SSF

\begin{tabular}{|c|c|c|c|}
\hline S. No & Prodigiosin Production media & Yield (g/l) & Reference \\
\hline $\begin{array}{l}1 \\
2 \\
3 \\
4 \\
5 \\
6 \\
7 \\
8 \\
9 \\
10 \\
12 \\
13 \\
14 \\
15 \\
16 \\
17 \\
18 \\
19 \\
20 \\
21 \\
22 \\
23 \\
24 \\
25 \\
26\end{array}$ & $\begin{array}{c}\text { Nutrient broth } \\
\text { Peptone glycerol broth } \\
\text { Sesame seed broth } \\
\text { Sesame oil broth } \\
\text { Peanut oil broth } \\
\text { Peanut seed broth } \\
\text { Copra seed broth } \\
\text { Coconut oil broth } \\
\text { Glucose } \\
\text { Dextrose broth with casein } \\
\text { Ethanol } \\
\text { Ethanol and glucose } \\
\text { Casein broth } \\
\text { Sesame oil broth } \\
\text { Corn steep mannitol medium } \\
\text { Mannitol medium } \\
\text { Corn steep medium } \\
\text { Cassava waste mannitol medium } \\
\text { Cassava waste medium } \\
\text { Luria Bertani glucose medium } \\
\left.\text { (NH })_{4}\right)_{2} \text { PO }_{4}^{+} \text {salt } \\
\text { Glucose-glycerol medium } \\
\text { Animal fleshing solid waste } \\
\text { Kitchen waste* } \\
\text { Tannery animal fleshing solid waste* }\end{array}$ & $\begin{array}{c}1.9 \\
1.35 \\
16.68 \\
0.767 \\
2.89 \\
38.75 \\
1.94 \\
1.42 \\
0.005 \\
1.3 \\
3 \\
3 \\
4.28 \\
0.66 \\
37.5 \\
34.00 \\
25.60 \\
49.50 \\
27.00 \\
13.50 \\
1.397 \\
5.83 \\
8.3 \\
4.155(\mathrm{~g} / \mathrm{kg}) \\
88.91(\mathrm{~g} / \mathrm{kg})\end{array}$ & $\begin{array}{c}{[18]} \\
{[18]} \\
{[14]} \\
{[14]} \\
{[14]} \\
{[14]} \\
{[14]} \\
{[14]} \\
{[27]} \\
{[26]} \\
{[24]} \\
{[25]} \\
{[28]} \\
{[17]} \\
{[16]} \\
{[16]} \\
{[16]} \\
{[16]} \\
{[16]} \\
{[16]} \\
{[19]} \\
{[28]} \\
{[9]} \\
{[15]} \\
\text { Present } \\
\text { study }\end{array}$ \\
\hline \multicolumn{4}{|c|}{ *solid state fermentation } \\
\hline
\end{tabular}

Table 3: Comparison of prodigiosin production with different growth medium

to $30 \%(\mathrm{w} / \mathrm{w})$ (Figure 4). The influence of above selected fermentation factors on prodigiosin production by this microbial strain, where minimum and maximum prodigiosin production obtained from 21.58 to $70.4 \mathrm{~g} / \mathrm{kg}$ TF respectively. These results suggest that fermentation parameters greatly influenced the production of prodigiosin with this microbial strain and amino acids from TF played an important role in the biosynthesis of prodigiosin because of their regulatory role in the induction or repression of the prodigiosin production. Similarly, Sumathi et al 2014 also considered TF (animal protein) as the substrate in submerged fermentation for the production of prodigiosin. This present investigation focused on the solid state fermentation for the prodigiosin production. The solid state fermentation carried out in laboratory scale drum fermenter. The fermenter was designed with provision to extract prodigiosin after completion of fermentation. The prodigiosin production was favored by wheat bran (plant protein) with the TF (animal protein). The combination of plant (wheat bran) and animal (TF) proteins enhanced the prodigiosin production. The animal proteins helped the microbial growth and plant proteins provided the hydroxyl proline for the biosynthesis of prodigiosin. The hydroxyl proline mainly involved in the biosynthesis of prodigiosin production. The TF consists of proteins by 50 to $60 \%$ of protein and lipid by 10 to $20 \%$, the protein content provide amino acids for the formation of prodigiosin biosynthesis and the lipids provide carbon in the form of glycerol and fatty acid to enhance the prodigiosin production. This data helps in simulation of economic fermentation medium especially, with respect to selection of environmental factors and $\mathrm{TF}$ concentrations in scale-up studies to induce maximum prodigiosin production using Serratia marcescens.

\section{Characterization of prodigiosin}

The fermented products before and after SSF were analyzed by diffuse reflectance spectroscopy. The change in colour was observed in SSF mixture from yellow to red denoted the presence of prodigiosin in solid state fermented medium (Figure 5). The Figure 6 shows a peak at $\lambda_{532} \mathrm{~nm}$ in the final fermented mixture, this is considered to be the 

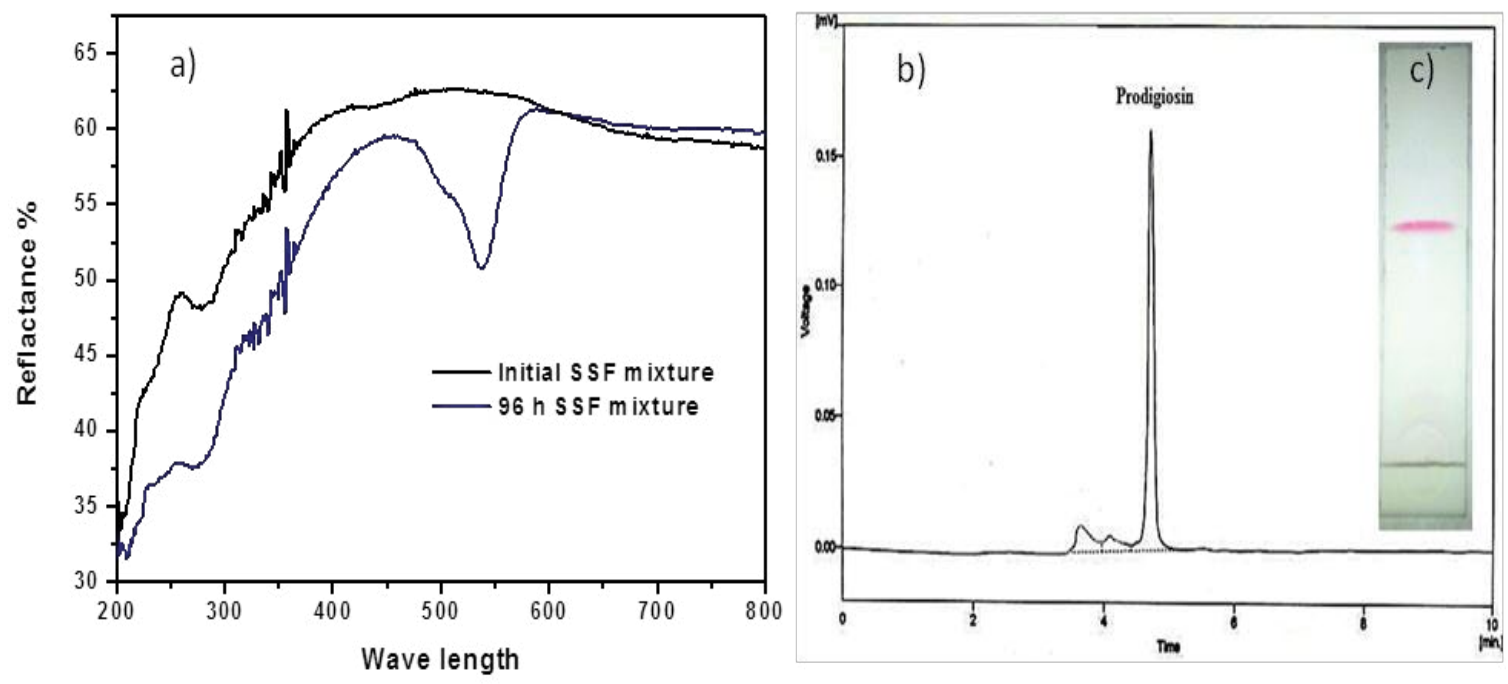

Figure 6: Characterization of purified prodigiosin by a) Diffuse reflectance spectroscopy b) High performance liquid chromatography, c) Thin layer chromatography.

characteristic peak of prodigiosin [29]. The fermentation medium, before fermentation contained no peak at $\lambda_{532} \mathrm{~nm}$. The HPLC analysis was showed the $>95 \%$ purity of the compound with single peak at retention time of $4.523 \mathrm{~min}$ as shown in Figure 6 [30].

\section{Antimicrobial activity of prodigiosin}

In the present investigation, the susceptibility of bacteria to inhibition towards the prodigiosin was assessed against $P$. aeruginosa and compared with conventional antibiotic compounds. The antimicrobial effect of prodigiosin was assessed on the basis of the zone of inhibition in the agar plate method. The prodigiosin impregnated disc showed the maximum zone of inhibition against $P$. aeruginosa $(14 \mathrm{~mm})$ as shown in Figure 7 . The erythromycin, chloramphenicol and tetracycline were inhibited the $P$. aeruginosa growth with zone of influence 6,9 and $7 \mathrm{~mm}$ respectively. The prodigiosin exhibited more inhibition activity against $P$. aeruginosa compared with conventional antibiotic compounds. The ampicillin and bacitracin showed no inhibition of bacterial growth. The bacterial cell viability in antibiotic containing solution was investigated by fluorescence microscopic LIVE/DEAD assay. Fluorescent image of erythromycin and tetracycline containing bacterial solution showed 40 and $50 \%$ of bacterial cells with red colour. The prodigiosin and chloramphenicol solution showed 75 and $98 \%$ of bacterial cells with red colour. The red colored cell indicate, the propidium iodide stain was attached with the dead bacterial cell due to the presence of nucleic acid functional sites in the bacterial cell membrane [31]. The red colored cells indicated the dead cells because the addition of the propidium iodide was directly attached to the nucleic acid site. The nucleic acid leakage was occurred only in dead/damaged cells. The propidium iodide was attached with the nucleic acid site of the dead cells. So the dead cells only could emit the red fluorescent light under the fluorescent light due to the presence of propidium iodide. There were no red colored cells in ampicillin containing solution because the bacteria could survive in the presence of ampicillin and bacitracin. However, the prodigiosin containing bacterial cells were completely killed. It may due to the mechanism of action on the inhibition of cell wall biosynthesis, protein synthesis,

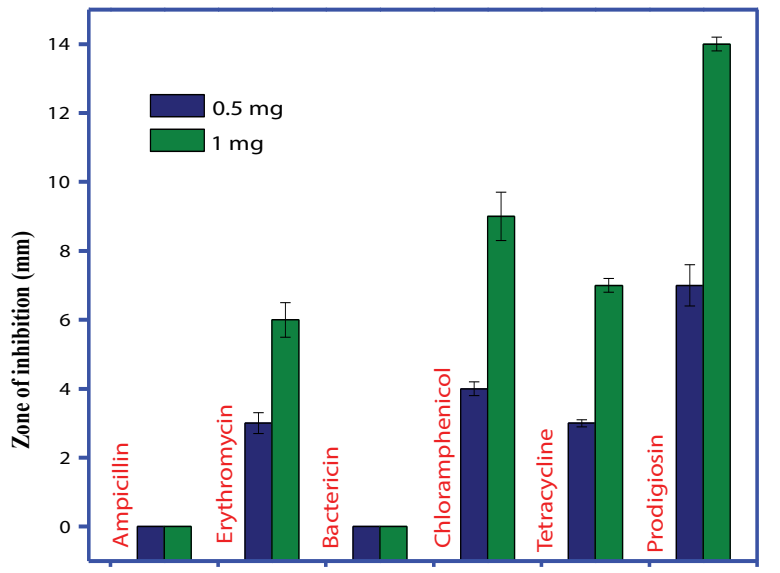

Figure 7: Antimicrobial activity of prodigiosin against $P$. aeruginosa by disc diffusion method.

and DNA synthesis as described by peach et al 2013 [31,32]. Moreover, the same bacterial removal pattern was observed with illuminometer (Figure 7). The $P$. aeruginosa could emit the fluorescence light under the illuminometer. The ampicillin and bacitracin exposed solution were showed high fluorescence emission because the $P$. aeruginosa population was high in the ampicillin and bacitracin exposed solution. Erythromycin and tetracycline exposed $P$. aeruginosa solution showed less fluorescence emission and no fluorescence emission was observed in chloramphenicol and prodigiosin exposed P. aeruginosa solution. This indicate that the $P$. aeruginosa was completely eliminated in the prodigiosin and chloramphenicol containing solution. The prodigiosin is the effective antimicrobial compound compared to ampicillin, bacitracin, tetracycline and erythromycin. The fluorescence emission image also confirms the antimicrobial efficiency of prodigiosin on $P$. aeruginosa comparatively higher than conventional antibiotic compounds (Figure 8). The antimicrobial activity of prodigiosin 
Citation: Arivizhivendhan KV, Mahesh M, Regina Mary R, Sekaran G (2015) Bioactive Prodigiosin Isolated from Serratia marcescens using Solid State Fermenter and its Bactericidal Activity Compared with Conventional Antibiotics. J Microb Biochem Technol 7: 305-312. doi:10.4172/19485948.1000230
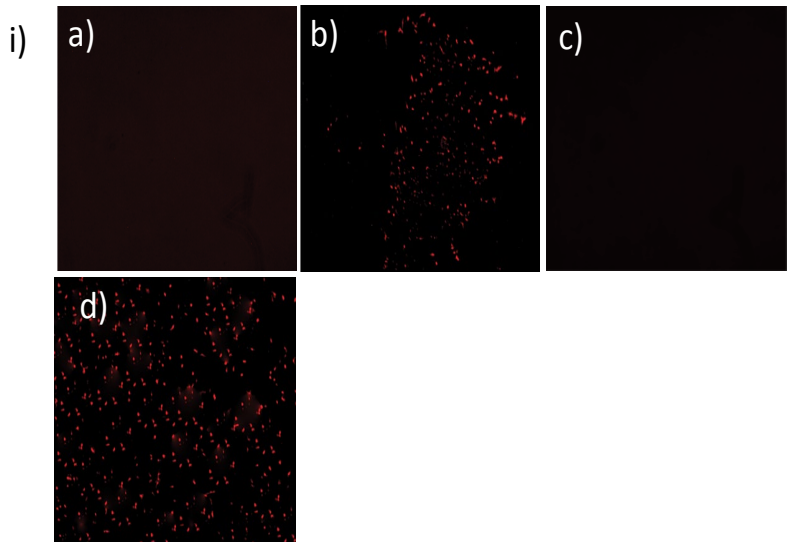

ii)

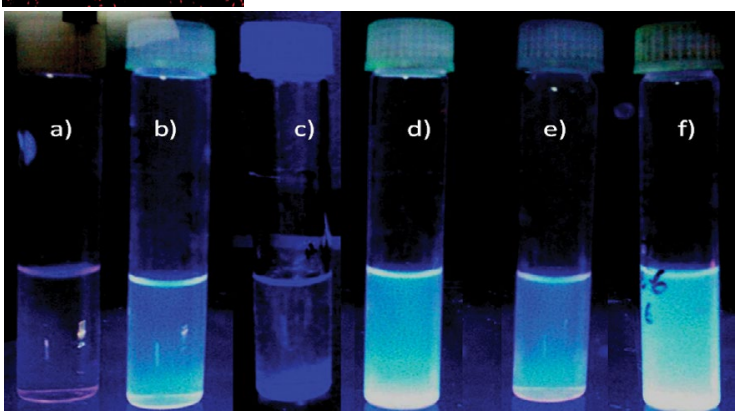

Figure 8: i) The fluorescence microscopy and ii) fluorescence illuminometer image represent the $P$. aeruginosa removal efficiency of a) prodigiosin b) erythromycin c) chloramphenicol, d) ampicillin e) tetramycin, f) bacitracin.

purchased from the Sigma Aldrich was similar with a conventional antibiotic as described by Jie Feng 2015 [33]. This present study shows prodigiosin has high antimicrobial activity compared than other antibiotic. The prodigiosin was effective enough to inhibit the activity of $P$. aeruginosa growth even at low concentration [9,34-38].

\section{Conclusion}

The present investigation provides the scope for effective production of pharmaceutical important secondary metabolite, prodigiosin from TF by solid state fermentation using Serratia marcescens. The Solid state fermenter shows high yield of prodigiosin production compared with submerged fermentation as reported earlier. The maximum prodigiosin $(70.4 \mathrm{mg} / \mathrm{kg}$ of $\mathrm{TF})$ yield was obtained at conditions such as fermentation time, $96 \mathrm{~h}$; $\mathrm{pH}-7$; temperature, $20^{\circ} \mathrm{C}$ and moisture content, $50 \%$ and $\mathrm{TF}, 30 \%$. The prodigiosin exhibited high antimicrobial activity against $P$. aeruginosa compared to other antibiotic compound. The antimicrobial potential of prodigiosin may make a possible platform in future for bacterial disinfection in clinical/ pharmaceutical wastewater.

\section{Acknowledgement}

The financial assistance under CSIR- STRAIT (CSC0201) programme is highly acknowledged.

\section{References}

1. Kanakaraj J, Rafiuddinamed M, John sundar V, Jayakumar R (2001) Reactive proteinoid in tanning process. Indian pat 1063/DEL/2001.

2. Kirk DW, Chan CC, Marsh $\mathrm{H}$ (2002) Chromium behavior during thermal treatment of MSW fly ash. J Hazard Mater 90: 39-49.
3. Suseela Rajakumar R, Ramanujam A (2010) Anaerobic co-digestion of hazardous tannery solid waste and primary sludge: biodegradation kinetics and metabolite analysis, Clean Tech Environ Policy 12: 517-524.

4. Assefa G, Eriksson O, Frostell B (2005) Technology assessment of therma treatment technologies using ORWARE, Energy Conver Manage 46: 797-819.

5. Bajza Z, Markovic I (1999) Influence of enzyme concentration on leather waste hydrolysis kinetics, J Soc Leath Tech Ch 83: 172-176.

6. Ganesh Kumar A, Swarnalatha S, Sairam B, Sekaran G (2008) Production of alkaline protease by Pseudomonas aeruginosa using proteinaceous solid waste generated from leather manufacturing industries. Bioresour Technol 99: 1939-1944.

7. Ravindran B, Dinesh SL, Kennedy LJ, Sekaran G (2008) Vermicomposting of solid waste generated from leather industries using epigeic earthworm Eisenia foetida. Appl Biochem Biotechnol 151: 480-488.

8. Lapenda JC, Silva PA, Vicalvi MC, Sena KX, Nascimento SC (2015) Antimicrobial activity of prodigiosin isolated from Serratia marcescens UFPEDA 398. World J Microbiol Biotechnol 31: 399-406.

9. Sumathi C, MohanaPriya D, Swarnalatha S, Dinesh MG, Sekaran G5 (2014) Production of prodigiosin using tannery fleshing and evaluating its pharmacological effects. ScientificWorldJournal 2014: 290327.

10. Wang HX, Ng TB (2000) Quinqueginsin, a novel protein with anti-human immunodeficiency virus, antifungal, ribonuclease and cell-free translation inhibitory activities from American ginseng roots. Biochem Biophys Res Commun 269: 155-159.

11. Pandey A, Soccol CR, Nigam P, Brand D, Mohan R, et al. (2000) Biotechnological potential of coffee pulp and coffee husk for bioprocesses. Biochem Eng J 6: 153-162.

12. Harris AKP, Williamson RN, Slater H, Cox A, Abbasi S, et al. (2004) The Serratia gene cluster encoding biosynthesis of the red antibiotic, prodigiosin shows species and strain-dependent genome context variation. Microbiology 150: $3547-3560$.

13. Shahitha S, Poornima K (2012) Enhanced prodigiosin production in Serratia Marcescens. J Appl Pharma Sci 2: 138-140.

14. Kamble KD, Hiwarale VD (2012) Prodigiosin production from serratia marcescens strains obtained from farm soil. Int J Environ Sci 5: 10-16.

15. Venil CK, Lakshmanaperumalsamy P (2009) Application of statistical design to the optimization of culture medium for prodigiosin production by Serratia marcescens SWML08. Malay J Microbiol 5: 55-60.

16. Chen WC, Yu WJ, Chang CC, Chang JS, Huang SH, et al. (2013) Enhancing production of prodigiosin from Serratia marcescens C3 by statistical experimental design and porous carrier addition strategy. Biochem Eng 78 : 93-100.

17. Giri AV, Anandkumar N, Muthukumaran G, Pennathur G (2004) A nove medium for the enhanced cell growth and production of prodigiosin from Serratia marcescens isolated from soil. BMC Microbiol 4: 11 .

18. Fang $X$, Shunxiang $X$, Qiyin $Y$ (2011) Strategy for Obtaining Inexpensive Prodigiosin Production by Serratia marcescens. Bio Environ Eng 20: 32-36.

19. Helvia W, Casullo DE, Araújo K, Galba M, Campos T (2010) Prodigiosin Production by Serratia marcescens UCP 1549 Using Renewable-Resources as a Low Cost Substrate. Molecules 15: 6931-6940.

20. Wei YH, Chen WC (2005) Enhanced production of prodigiosin-like pigment from Serratia marcescens SMdeltaR by medium improvement and oilsupplementation strategies. J Biosci Bioeng 99: 616-622.

21. Wei YH, Yu WJ, Chen WC (2005) Enhanced undecylprodigiosin production from Serratia marcescens SS-1 by medium formulation and amino-acid supplementation. J Biosci Bioeng 100: 466-471.

22. Stankovic N, Radulovic V, Petkovic M, Vuckovic I, Jadranin M, et al. (2012) Streptomyces sp. JS520 produces exceptionally high quantities of undecylprodigiosin with antibacterial, antioxidative, and UV-protective properties. Appl Microbiol Biotechnol 96: 1217-1231.

23. Clements Jewery S (1976) The reversal of glucose repressed prodigiosin production in Serratia marcescens by the cyclic $3^{\prime} 5$ '-adenosine monophosphate inhibitor theophylline. Experientia 32: 421-422. 
Citation: Arivizhivendhan KV, Mahesh M, Regina Mary R, Sekaran G (2015) Bioactive Prodigiosin Isolated from Serratia marcescens using Solid State Fermenter and its Bactericidal Activity Compared with Conventional Antibiotics. J Microb Biochem Technol 7: 305-312. doi:10.4172/19485948.1000230

24. Kalivoda EJ, Stella NA, Aston MA, Fender JE, Thompson PP, et al. (2010) Cyclic AMP negatively regulates prodigiosin production by Serratia marcescens. Res Microbiol 161: 158-167.

25. Chang CC, Chen WC, Ho TF, Wu HS, Wei YH (2011) Development of natural anti-tumor drugs by microorganisms. J Biosci Bioeng 111: 501-511.

26. Cang S, Sanada M, Johdo O, Ohta S, Nagamatsu Y et al. (2000) High production of prodigiosin by Serratia marcescens grown on ethanol. Biotchnol Lett 22: 1761-1765.

27. Manderville RA1 (2001) Synthesis, proton-affinity and anti-cancer properties of the prodigiosin-group natural products. Curr Med Chem Anticancer Agents 1: 195-218.

28. Jin-li T, Xue-dong W, Ya-ling S, Dong-zhi W (2005) Strategy for the improvement of prodigiosin production by a Serratia marcescens mutant through fed-batch fermentation. World J Microb Biotech 21: 969-972.

29. HARNED RL (1954) The production of prodigiosin by submerged growth of Serratia marcescens. Appl Microbiol 2: 365-368.

30. Song MJ, Bae J, Lee DS, Kim CH, Kim JS, et al. (2006) Purification and characterization of prodigiosin produced by integrated bioreactor from Serratia sp. KH-95. J Biosci Bioeng 101: 157-161.

31. Arivizhivendhan KV, Boopathy R, Maharaja P, Regina Mary R, Sekaran G (2015) Bioactive prodigiosin-impregnated cellulose matrix for the removal of pathogenic bacteria from aqueous solution. RSC Advances 5: 68621-68631.
32. Peach KC, Bray WM, Winslow D, Linington PF, Linington RG (2013) Mechanism of action-based classification of antibiotics using high-content bacterial image analysis. Mol Biosyst 9: 1837-1848.

33. Jie Feng, Wanliang Shi, Shuo Zhang, Ying Zhang Identification of new compounds with high activity against stationary phase Borrelia burgdorferi from the $\mathrm{NCl}$ compound collection. Emerging Microbes and Infections 1-15.

34. Geetha ramani D, nair A, Krithika K (2014) Optimization of cultural conditions for the production of Prodigiosin by serratia marcescens and screening for the antimicrobial activity of prodigios. Int J Pharm Bio Sci 5: 383-392.

35. Mekhael R, Yousif SY (2009) The role of red pigment produced by serratia marcescens as Antibacterial and plasmid curing agent. J Duhok univ 1: 268-274.

36. Ananda priya, S Satheesh, B Ashokkumar, P Varalakshmi, G Selvakumar, et al. (2013) Antifouling activity of prodigiosin from estuarine isolate of serratia marcescens CMST07. Microbiol Res Agroeco Manage 16: 11-21.

37. Mamunur rashid Md, Fakruddin Md, Reaz MM, Fatema K, Alimuddin chowdhury MD (2014) Anti-bacterial activity of pigments isolated from pigment-forming soi bacteria. British J Pharma Research 4: 880-894.

38. Sathish kumar T, Aparna H (2014) Anti-biofouling activity of prodigiosin, a pigment extracted from serratia marcescens. Int J Curr Microbiol App Sci 3: 712-725. 